\title{
Evaluation of Primary Metabolites and Antioxidant Potential Activity of Cayratia trifolia (Leaf and Stems)
}

\author{
*Anita ${ }^{1}$, Nakuleshwer Dut Jasuja ${ }^{1}$ and Manas Mathur ${ }^{2}$ \\ ${ }^{* 1}$ Department of Agriculture, Vivekananda Global University, Jaipur (India) \\ 22 Seminal Applied Sciences Pvt. Ltd. Jaipur (India)
}

\begin{abstract}
Cayratia trifolia Linn. Domin Syn. Vitis trifolia (Family: Vitaceae) is commonly known as Fox grape in English; Amlabel, Ramchana in Hindi and Amlavetash in Sanskrit. It is native to Asia and Australia. This plant is used for chronic fever, rheumatic, anti-inflammatory etc. In the present study, quantitative analysis and free radical scavenging activities of stem ethanolic extract of Cayratia trifolia was investigated. The extract was found to possess more secondary metabolites and it exhibit radical scavenging activities, Based on the results it can be concluded that, the stem ethanolic extract of Cayratia trifolia which contains high amount of secondary metabolites and exhibits free radical scavenging activities, phytochemistry from leaves and stems using spectral techniques. This research paper provides information mainly on various biological activities like antimitotic, antidiabetic and anti-implantation and several medicinal uses. Biological activities of few of them have been studied maximum concentration of Proteins $(58.4 \mathrm{mg} / \mathrm{gdw})$ and minimum concentration in total soluble sugar $(0.7 \mathrm{mg} / \mathrm{gdw})$ and maximum concentration of Lipid peroxidase $(5.01 \mathrm{mg} / \mathrm{gdw})$ and minimum concentration in FRAP $(0.197 \mathrm{mg} / \mathrm{gdw})$.
\end{abstract}

Keywords: Cayratia trifolia; Vitaceae; Phytochemistry; Antioxidant.

Article Info: Received 08 July 2019; Review Completed 21 Aug 2019; Accepted 26 Aug 2019; Available online 30 Aug 2019

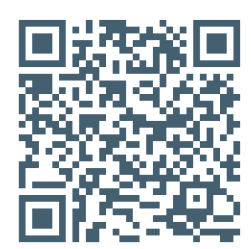

Cite this article as:

Anita, Jasuja ND, Mathur M, Evaluation of Primary Metabolites and Antioxidant Potential Activity of Cayratia trifolia (Leaf and Stems), Journal of Drug Delivery and Therapeutics. 2019; 9(4-A):367-372 http://dx.doi.org/10.22270/jddt.v9i4A.3492

*Address for Correspondence:

Anita, Department of Agriculture, Vivekananda Global University, Jaipur (India)

\section{INTRODUCTION}

According to World Health Organization, traditional medicine is defined as diverse health practices, approaches, and knowledge and believes incorporating plant, animal and/or mineral-based medicines, spiritual therapies, manual techniques and exercises applied singularly or in combination to maintain well-being as well as to treat, diagnose or prevent illness (Lewington A., 1993; Maurya R. and Gupta CM. 2006). More than 35,000 plant species are being used in various human cultures around the world for medicinal purposes (World Health Organization; 2008). Crude drugs are usually the dried parts of medicinal plants (roots, stem wood, bark, leaves, flowers seeds, fruits and whole plants, etc.) that form the essential raw materials for the production of traditional remedies in various systems of medicines like Ayurveda, Siddha, Unani, Homeopathy, Tibetan etc.

The present study is aimed to isolate and characterize few phytoconstituents from the methanolic extract of Cayratia trifolia (Linn.) Domin. Cayratia trifolia (Linn.) Domin (Vitaceae) is a perennial climber, commonly known as
Amalbel and Ramchana in Hindi; and Amlavetash in Sanskrit, found in India, Asia and Australia (Gupta J, et al., 2012). The plant is found in hilly regions as well as the hotter part of India from Jammu and Rajasthan to Assam.

Cayratia trifolia Linn. Domin syn. Vitis trifolia Linn. (Family:Vitaceae) is a native of India, Asia and Australia. It is a perennial climber, found in the hotter parts of India from Jammu and Rajasthan to Assam, Tripura and West Bengal extending into peninsular India up to $600 \mathrm{~m}$ (Sesagirriravu et al., 1986). The three-leaf cayratia (Cayratia trifolia (L.) Domin., Family Vitaceae), locally known in the Philippines as kalit-kalit, is a weak herbaceous climber in thickets and open forests at low altitudes. It is widely distributed in tropical and subtropical Asia, Africa, India, Australia and Pacific islands where its wide-ranging medicinal values are welldocumented both in folk medicine and pharmacological studies. Leaf decoction or the juice of the fresh leaves is used to cure scurvy in the Philippines, to prevent head itch and dandruff in Java, to relieve inflammation and high fever in Thailand and Peninsular Malaysia while the young leaves are eaten as vegetable in Mluccas. The root is used as an 
antidote against snake bites. (Choudhary et al., 2008). Natural substances in plants and fruits have the potentials to be developed as anticancer drugs (Safarzadeh E et al., 2014; Yin SY et al., 2013). One of them is Cayratia trifolia ( $C$. trifolia) which is one of the tropical plants belong to the family of Vitaceae. It is a wild plant species that are easy to find in the forest, especially in the riverside. Parts of $C$. trifolia, that is often used are fruit, stem and leaf. It has been used empirically to treat various types of diseases (Kumar D, et al., 2012; Gupta J and Kumar D, 2011).

The medicinal values of plants are dictated by their phytochemical and other chemical constituents (Fallah HSM, et al., (2005). Plant extracts contain many chemical compounds which are biologically active within the human body (Liu Y and Yang L. (2006). Plant-derived substances have recently become of great interest owing to their versatile applications (Ncube NS, et al., (2008). Scientific studies on a number of medicinal plants indicated that promising phytochemical compounds can be developed for many health problems (Gupta SS. (1996). Still most of the plants carry a large number of unidentified compounds which can be really useful for making new drugs and for the identification of lead compounds.

Free radicals are incessantly produced in the human body, as they are essential for energy supply, detoxification, chemical signaling and immune function (Gulcin I., (2005). These free radicals are usually produced through aerobic respiration. Although the human body produces antioxidant enzymes to neutralize the free radicals (Rimbach $G$, et al., (2005). When the generation of ROS overtakes the antioxidant defense of the cells the free radicals start attacking cellular proteins, lipids and carbohydrates leading to the pathogenesis of many disorders including arthritis and connective tissue disorders, liver disorders, neurodegenerative disorders, cardiovascular disorders, diabetes, chronic inflammation, mutagenesis, carcinogenesis and in the process of ageing (Rajeshwar Y, et al., (2005). Antioxidants give protection for living organisms from harm caused by uncontrolled production of

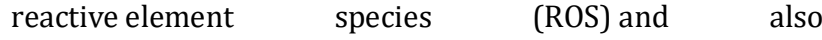
the concomitant lipid peroxidation,

macromolecule harm and DNA strand breaking (Ghoshal S, et al., (1996).

Antioxidants reduce the oxidative stress in cells and are therefore useful in the treatment of many human diseases, including cancer, cardiovascular diseases and inflammatory diseases. This activity is due to the ability of antioxidants to reduce oxidative stress by neutralizing or scavenging of reactive species by hydrogen donation (Erkan $\mathrm{N}$, et al., (2008). Recent studies have confirmed that free radicals would damage nearby structures including DNA, proteins or lipids. Radical scavenging antioxidants are mainly significant in protecting cells from the injury of free radical (Youwei $\mathrm{Z}$, et al., (1856). Thus, antioxidants with free radical scavenging activities may have enormous significance in the prevention and therapeutics of diseases (Saha MR, et al., (2008).

\section{Synonyms}

Cayratia trifolia is also known by various synonyms, such as: Vitis trifolia Linn, Cissus carnosa Lamk, Vitis carnosa (Lamk.) Wall.ex M. Lawson, Cissus trifolia (Linn.) K. Schaum, Cayratia carnosa (Lamk.) Gagnep.

\section{Local Names}

Different vernacular names of Cayratia trifolia have been reported in Table 1 (Gupta A. et al., 2011).
Table 1: Vernacular names of Cayratia trifolia.

\begin{tabular}{|l|l|}
\hline \multicolumn{2}{|l|}{ Vernacular names of Cayratia trifolia } \\
\hline Language & Vernacular Names \\
\hline English & Fox-grape, Bush-grape \\
\hline Hindi & Amal-bel, Ramchana, Tamnya \\
\hline Marathi & Ambatvel \\
\hline Tamil & Kattuppiranti \\
\hline Malyalam & Amarcakkoti \\
\hline Sanskrit & Amlavetasah \\
\hline
\end{tabular}

\section{TAXONOMICAL HIERARCHY}

The taxonomical hierarchy (Purushothama S, et al., (2001); Bradacs G., (2008) of Cayratia trifolia has been mentioned in Table 2.

Table 2: Taxonomical hierarchy of Cayratia trifolia

\begin{tabular}{|ll|}
\hline Taxonomical hierarchy & Names \\
\hline Kingdom & Plantae \\
\hline Class & Magnolipsida \\
\hline Order & Vitales \\
\hline Family & Vitaceae \\
\hline Genus & Cayratia \\
\hline Species & trifolia \\
\hline & \\
\hline
\end{tabular}

\section{Botanical Distribution}

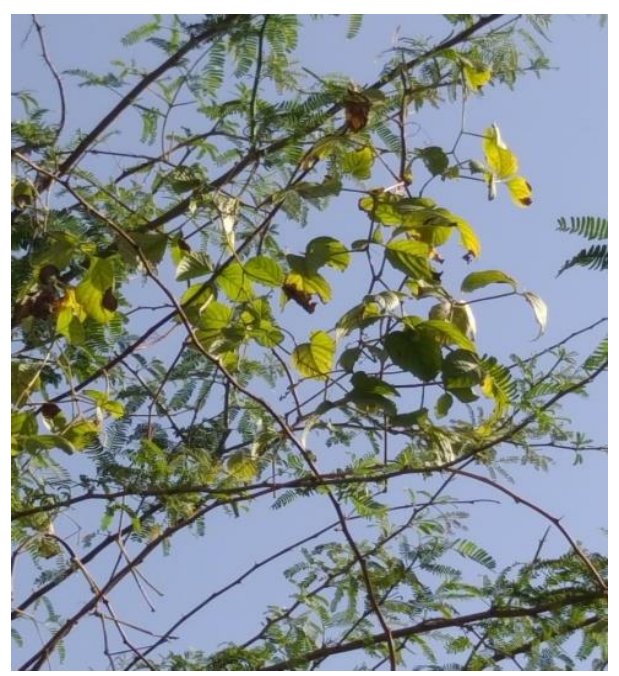

Cayratia trifolia is a weak herbaceous climber, woody at base, stem is more or less succulent, compressed and densely. Leaf and stems are tri-foliolate with petioles $2-3-\mathrm{cm}$ long. Leaflets are ovate to oblong-ovate, 2-8-cm long, 1.5-5$\mathrm{cm}$ wide, pointed at the tip. Flowers are small greenish white $2.5 \mathrm{~mm}$, and brown on solitary cymes in leaf axils (Garden CA and Bennet HW., (1956); Vardana R., (2008); Pulliah T., (2006). Fruits are fleshy, juicy, dark purple or black, nearly spherical and about $1 \mathrm{~cm}$ in diameter. Seeds are triangular, apex rounded, ventral holes and ribs obtuse along margin, slightly raised (Tutul E and Uddin MD. Z, (2010). 


\section{Geographical Distribution}

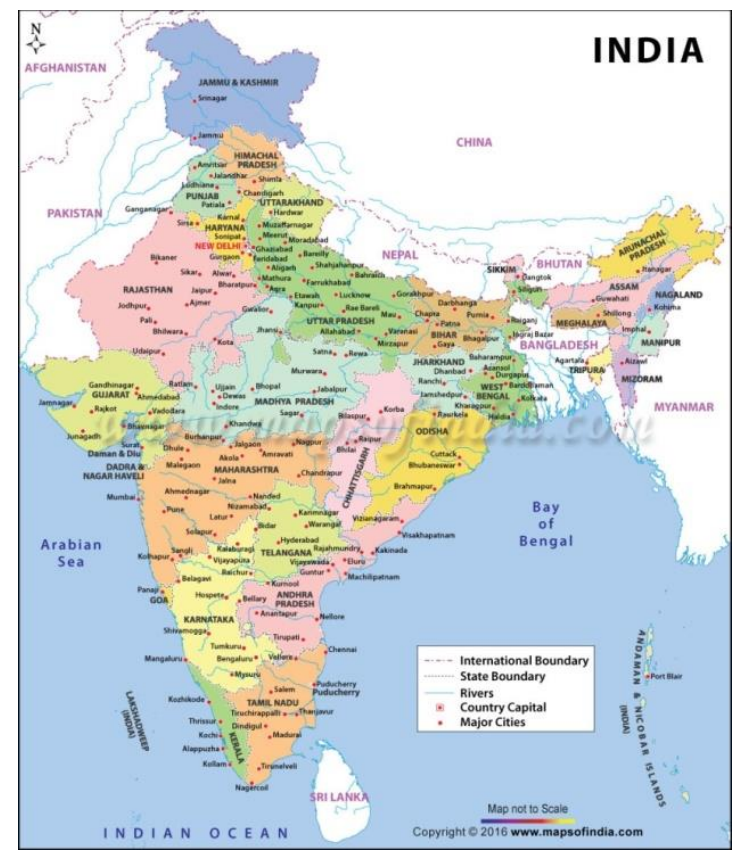

Cayratia trifolia is known as kalit--kalit in Philippines where it is found at low altitudes. It is also found from India to southern China, through the Malaya to the Moluccas and the Caroline Islands. It also found throughout the hilly regions in India (Tutul E and Uddin MD. Z, (2010); Manjuhatta BK, et al., (2004)). This perennial climber also grows wildly in Jammu, Rajasthan, Assam, Tripura and West Bengal extending into peninusular India up to $600 \mathrm{~m}$ (Gupta AK and Sharma M, (2007). This plant is also distributed in Bangladesh,

Burma, Ceylon, Combodia, Indonesia, Laos, Makaysia, Malacca, Pakistan, Thailand and Vietnam (Soejima A and Wen J. (2005); Lee CC and Houghton P. (2005)). It is found in tropical and subtropical areas of Asia, Africa, Australia and Island of the Pacifi c Ocean (Defl ilipps AR and Maina LS. (1988)).

\section{Chemical Constituents}

This plant also contains kaempferol, myricetin, quercetin, triterpenes and epifriedelanol (Munchen, (1953). Whole plant of Cayratia trifolia has been reported to contain yellow waxy oil, steroids/terpenoids, fl avonoids, tannins (Gupta AK and Sharma

M, (2007). Leaves contain stilbenes such as piceid, reveratrol, viniferin and ampelopsin (Arora J, et al., (2009). Stem, leaves and roots are reported to possess hydrocyanic acid and delphinidin. Several $\mathrm{fl}$ avonoids such as cyanidin are reported in the leaves (Grubben GJ and Denton OA. (2004); Throton WBC. Krakatau. (1997). Its seeds and fruits showed presence of cyanogenic compounds. Fruits also contain calcium oxalate responsible for severe irritation in the mouth (Gupta AK and Sharma M, (2007).

\section{MATERIAL AND METHODS}

Sample collect from Distt. Sawaimadhopur Rajasthan, Cayratia trifolia (leaf and stems) and experimental plant parts were deposit in the herbarium of Department of Botany, University of Rajasthan, Plant RUBL No. 211682 and shade dry and make it powder form.

\section{Primary Metabolites:}

\section{Preparation of Plant Extracts}

- Carbohydrates (Total soluble sugar and Starch): - 80\% ethanol use for extraction,

- Protein: - 10\% TCA use for protein extraction.

- Lipid: - Distilled water is used for lipid extraction.

- Phenol: - 80\% ethanol is used for phenol extraction.

Estimation of primary metabolites:

Primary metabolites directly involved in growth and development while secondary metabolites are not involved directly and they have been worked as biocatalysts. Primary metabolites are of prime importance and essentially required for growth and development of plants. Many primary metabolites lie in their impact as precursors or pharmacologically active metabolites of pharmaceutical compounds such as Antipsychotic drugs etc.

\section{CARBOHYDRATE ESTIMATION}

Total soluble sugar: - $80 \%$ ethanol use for extraction according protocol was followed using the method of Mc Cready et al, (1950). $0.1 \mathrm{ml}$ of sample was mixed with $5 \mathrm{ml}$ of $80 \%$ ethanol reagent. Centrifuge at $10000 \mathrm{rpm}$ for $20 \mathrm{~min}$ then supernatant collects in test tube. Add $5 \mathrm{ml} \mathrm{H}_{2} \mathrm{SO}_{4}$ with $1 \mathrm{ml} 5 \%$ phenol then mix by vortex. Now kept sample at room temperature for 20 minutes. Absorbance was read at (wavlength) $490 \mathrm{~nm}$ against a reagent blank. The analysis was performed in triplicates and the results were expressed as mg/gram dry weight sample.

Starch: - The protocol was followed using the method of Loomis and Shull (1973) for total soluble sugar. Take $5 \mathrm{ml}$ of $80 \%$ ethanol in a test and mix with $0.1 \mathrm{ml}$ plant sample, mix properly with the help of vertex and centrifuge at 10000 rpm for 20 minutes, collect pellet and mix with $1 \mathrm{ml}$ perchloric acid $\left(\mathrm{HClO}_{4}\right)$ mix by vertex. Take $1 \mathrm{ml}$ sample in test tube add $5 \mathrm{ml} \mathrm{H}_{2} \mathrm{SO}_{4}$ and $1 \mathrm{ml} 5 \%$ phenol mixing by vortex keep 20 min room temp. The absorbance was read at $490 \mathrm{~nm}$ against a reagent blank. The analysis was performed in triplicates and the results were expressed as $\mathrm{mg} / \mathrm{g}$ dry weight.

\section{PROTEIN ESTIMATION: -}

$10 \%$ TCA use for protein extraction according here methodology of (Osborne, 1962) was followed. Take $0.1 \mathrm{ml}$ of sample mixed it with $3 \mathrm{ml} 10 \%$ TCA, centrifuge at 15000 rpm for 10 minutes, now take pellet add $10 \mathrm{ml} \mathrm{5 \%} \mathrm{TCA} \mathrm{mix}$ it by vortex. Now take in a test tube and incubate at $80{ }^{\circ} \mathrm{C}$ for 30 minutes, after incubation cool it and take $1 \mathrm{ml}$ sample from it and add $5 \mathrm{ml}$ alkaline solution with $1 \mathrm{ml}$ Folin \& Ciocalteu's reagent and incubated again for 10 minutes at 37 ${ }^{\circ} \mathrm{C}$ or room temperature. Absorbance was read at $750 \mathrm{~nm}$ (wavlength) against 10\% TCA reagent blank. The analysis was performed in triplicates and the results were expressed $\mathrm{mg} / \mathrm{g}$ dry weight sample.

\section{LIPID ESTIMATION: -}

Distilled water is used for lipid extraction according extraction methodology of Jay ram, (1981) will be followed. Take $0.3 \mathrm{gm}$ sample with $10 \mathrm{ml}$ distilled water and crush it with the help of mortar and pestle. Add $20 \mathrm{ml}$ chloroform $\left(\mathrm{CHCl}_{3}\right)$ with $10 \mathrm{ml}$ methanol $\left(\mathrm{CH}_{3} \mathrm{OH}\right)$ for 20 min kept on room temperature will filter it after $20 \mathrm{~min}$. Now add $20 \mathrm{ml}$ $\mathrm{CHCl}_{3}$ with $2 \mathrm{ml}$ distilled water then proper mixing. Take in separating flask and collect lower layer. Dry it here blank weight less in dry weight take result. The analysis was 
performed in triplicates and the results were expressed $\mathrm{mg} / \mathrm{g}$ dry weight sample.

\section{PHENOL ESTIMATION: -}

$80 \%$ ethanol is used for extraction total phenol content in each sample was estimated by spectrophotometer method of Bray and Thorpe (1954). Take 0.2 gm sample with $4 \mathrm{ml} 80 \%$ ethanol crush it with the help of mortar and pestle. Centrifuge at $10000 \mathrm{rpm}$ for 10 minutes and collect supernatant and take $1 \mathrm{ml}$ of sample added $1 \mathrm{ml}$ of Folin \& Ciocalteau reagent and incubated at room temperature for 3 minutes. After three minutes $2 \mathrm{ml}$ of $20 \%$ sodium carbonate (Na2CO3) was added, mixed well and incubated the tubes in boiling water bath for 1 minute. Cooled rapidly and read absorbance at $750 \mathrm{~nm}$ (wavlength) against reagent blank. The analysis was performed in triplicates and the results were expressed as $\mathrm{mg} / \mathrm{g}$ sample.

\section{ANTIOXIDANT ACTIVITY}

FRAP (Ferric reducing antioxidant power)

The FRAP assay was used to estimate the reducing capacity of plant extracts, according to the method of Benzie and Strain (1996). The FRAP reagent contained $2.5 \mathrm{~mL}$ of a 10 mM TPTZ solution in $40 \mathrm{mM} \mathrm{HCl}, 2.5 \mathrm{~mL}$ of $20 \mathrm{mM}$ $\mathrm{FeCl} 3.6 \mathrm{H} 2 \mathrm{O}$ and $25 \mathrm{~mL}$ of $300 \mathrm{mM}$ acetate buffer (pH 3.6). It was freshly prepared and warmed at $37^{\circ} \mathrm{C}$. $900 \mu \mathrm{l}$ FRAP reagent was mixed with $90 \mu \mathrm{l}$ water and $30 \mu \mathrm{l}$ of the extract. The reaction mixture was incubated at $37^{\circ} \mathrm{C}$ for 30 minutes and the absorbance was measured at $593 \mathrm{~nm}$.

\section{CATALASE}

Catalase activity in our laboratory is measured by a spectrophotometric procedure measuring peroxide removal. It is a direct assay with pseudo-first order kinetics and is measured by the method of Sinha K (1972). The enzyme extract $(0.5 \mathrm{ml})$ was added to the reaction mixture containing $1 \mathrm{ml}$ of $0.01 \mathrm{M}$ phosphate buffer ( $\mathrm{pH} 7.0$ ), $0.5 \mathrm{ml}$ of $0.2 \mathrm{M} \mathrm{H}_{2} \mathrm{O}_{2}, 0.4 \mathrm{ml} \mathrm{H} \mathrm{H}_{2} \mathrm{O}$ and incubated for different time period. The reaction was terminated by the addition of $2 \mathrm{ml}$ of acid reagent (dichromate/acetic acid mixture) which was prepared by mixing $5 \%$ potassium dichromate with glacial acetic acid (1:3 by volume). To the control, the enzyme was added after the addition of acid reagent. All the tubes were heated for 10 minutes and the absorbance was read at 610 $\mathrm{nm}$. Catalase activity was expressed in terms of $\mu$ moles of $\mathrm{H}_{2} \mathrm{O}_{2}$ consumed/min/mg protein.

LPO (Lipid peroxidase)

Homogenize $0.1 \mathrm{gm}$ of leaf tissue by adding $0.5 \mathrm{ml} 0.1 \%$ $(\mathrm{w} / \mathrm{v})$ TCA. Centrifuge the homogenate for $10 \mathrm{~min}$ (15000rpm, 4.0 $0^{\circ}$ C). Collect supernatant and mix $0.5 \mathrm{ml}$ of supernatant with $1.5 \mathrm{ml} 0.5 \%$ TBA diluted in $20 \%$ TCA. Incubate in water bath at $95^{\circ} \mathrm{C}$ for $25 \mathrm{~min}$. End reaction by incubating on ice. In case the solution is not clear, centrifuge for a further $5 \mathrm{~min}\left(15000 \mathrm{rpm}, 4.0^{\circ} \mathrm{C}\right)$. Measure the absorbance at 532 and $600 \mathrm{~nm}$ (Health \& Packer, (1968).

\section{PEROXIDASE}

The peroxidase assay was carried out by the method of Addy SK and Goodman RN (1972). The reaction mixture consisted of $3 \mathrm{ml}$ of buffered pyrogallol $(0.05 \mathrm{M}$ pyrogallol in $0.1 \mathrm{M}$ phosphate buffer ( $\mathrm{pH} 7.0$ ) and $0.5 \mathrm{ml}$ of $1 \% \mathrm{H}_{2} \mathrm{O}_{2}$. To this added $0.1 \mathrm{ml}$ plant extract and O.D. change was measured at $430 \mathrm{~nm}$ for every 30 seconds for 2 minutes. The peroxidase activity was calculated using an extinction coefficient of oxidized pyrogallol (4.5 litres/mol).

\section{RESULT \& DISCUSSION}

Medicinal plants are of great importance to health of individual and communities. The medicinal values of a plant lie in some chemical substances that produce a definite physiological action on the human body. Phytochemicals analysis is of paramount importance in identifying a new source of therapeutically and industrially valuable compounds having medicinal plants have been chemically investigated. In the present investigation primary metabolites was qualitatively and quantitatively analyzed using Cayratia trifolia leaves and stems.

\section{PRIMARY METABOLITES}

Total level of primary metabolites (mg/gram dry weight) in various plant parts

\begin{tabular}{|l|c|c|c|c|}
\hline \multicolumn{5}{|c|}{$\begin{array}{c}\text { Primary Metabolites extracts from Cayratia Trifolia leaf and stem } \\
\text { (mg/gram dry weight) }\end{array}$} \\
\hline \multirow{2}{*}{ Assay } & \multicolumn{3}{|c|}{ Leaves } & \multicolumn{2}{c|}{ Stem } \\
\cline { 2 - 5 } & OD of Test & Test Result & OD of Test & 1.65 \\
\hline Starch & 0.231 & 1.15 & 0.324 & 0.7 \\
\hline TSS & 0.237 & 1.2 & 0.141 & 58.4 \\
\hline Protein & 0.371 & 46.0 & 0.550 & 2.45 \\
\hline Phenol & 0.706 & 3.1 & 0.527 & 6.0 \\
\hline Lipid & - & 2.0 & - & \\
\hline
\end{tabular}




\section{GRAPHICAL PRESENTATION}

Total level of primary metabolites (mg/gram dry weight) in various plant parts

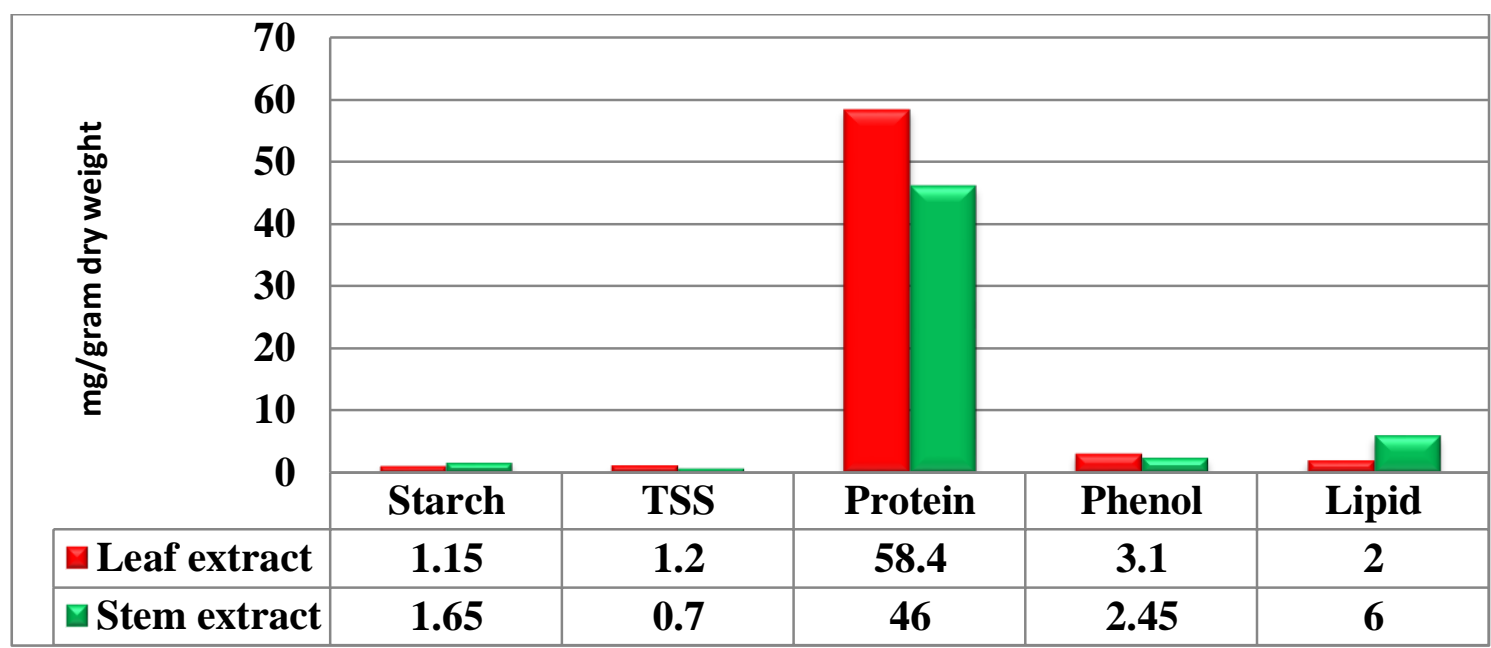

Antioxidant extraction from Cayratia trifolia leaf and stems ( $\mu \mathrm{M} / \mathrm{l} / \mathrm{gram}$ fresh weight)

\begin{tabular}{|l|c|c|c|c|}
\hline \multirow{2}{*}{} & \multicolumn{2}{|c|}{ Leaf } & \multicolumn{2}{c|}{$\begin{array}{c}\text { Stem } \\
(\mu \mathrm{M} / \mathrm{M} / \mathrm{l} / \mathrm{gram} \text { fresh weight })\end{array}$} \\
\hline & OD of Test & Result & OD of Test & Result \\
\hline LPO & 0.039 & 5.01 & 0.031 & 4.8 \\
\hline FRAP & 0.247 & 0.281 & 0.173 & 0.197 \\
\hline CATALASE & 0.015 & 0.65 & 0.017 & 0.68 \\
\hline PEROXIDASE & 0.169 & 0.473 & 0.158 & 0.442 \\
\hline
\end{tabular}

\section{GRAPHICAL PRESENTATION}

Total level of antioxidant ( $\boldsymbol{\mu M} / \mathbf{l} /$ gram fresh weight) in various plant parts

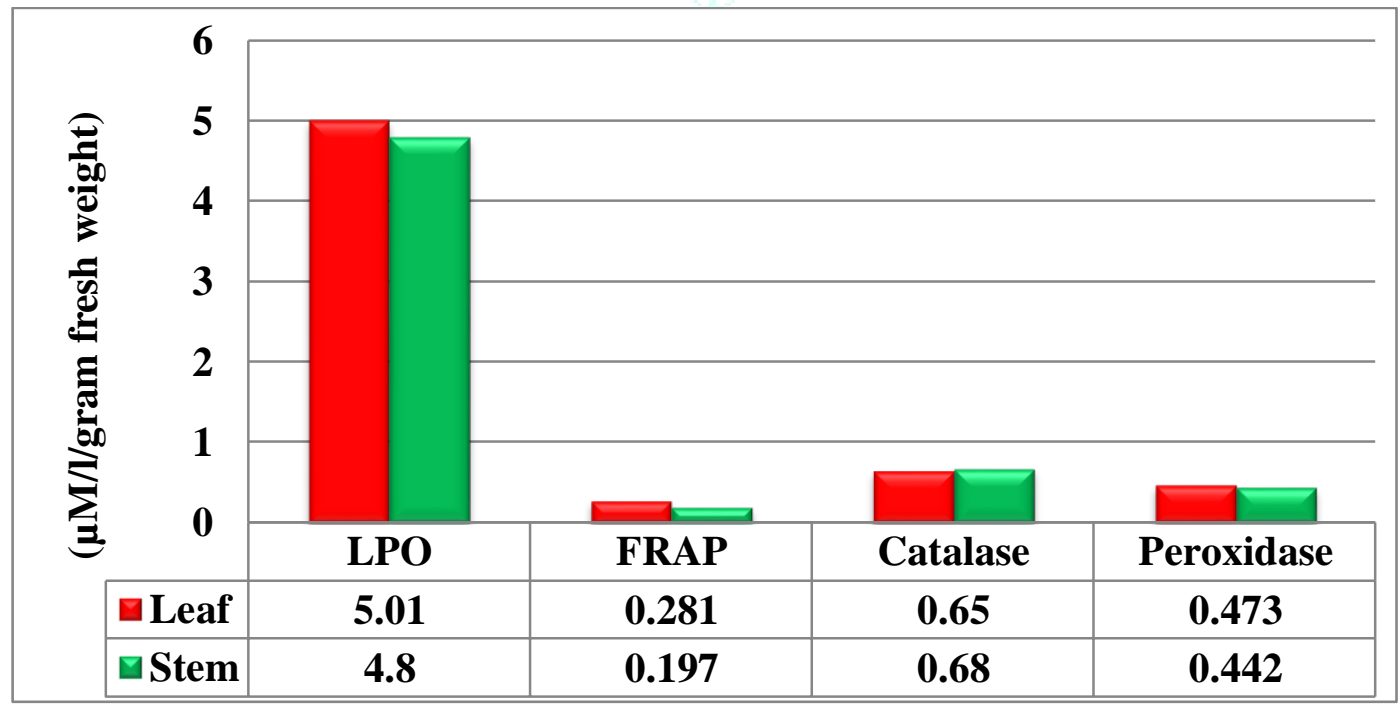

\section{CONCLUSION}

In the present study, quantitative analysis of primary metabolites and free radical scavenging activities of stem and leaves ethanolic extract of Cayratia trifolia was investigated. The extract was found to possess more primary metabolites and it exhibit radical scavenging activities, Based on the results it can be concluded that, the stem and leaves ethanolic extract of Cayratia trifolia which contains high amount of primary metabolites and exhibits free radical scavenging activities. In future this plant extract are significant sources of natural supplement which may be use cell repair and cell growth and antioxidant, which may be helpful in preventing the progress of various oxidative stresses and as a possible food supplement or in pharmaceutical industry.

\section{ACKNOWLEDGEMENTS}

The authors are thankful to UGC - CSIR (JRF) and Chancellor, Registrar and HOD Department of Agriculture of Vivekanand

CODEN (USA): JDDTAO 
Global University, Jaipur for providing facilities and encouragement.

\section{REFERENCES}

1. Addy SK and Goodman RN, Polyphenol oxidase and peroxidase in apple leaves inoculated with a virulent or an avirulent strain for Ervinia amylovora. Indian Phytopathology, 1972; 25:575-579

2. Arora J, Roat C, Goyal S, Ramawat KG. High Stilbenes accumulation in root culture of Cayratia trifolia (L.) Domin grown in shake fl ask. Acta Physiol Plant, 2009; 31:1307-1311.

3. Beers RF Jr, Sizer IW. A spectrophotometric method for measuring the breakdown of hydrogen peroxide by catalase. J Biol Chem. 1952; 195:133-140.

4. Benzie IFF and Strain JJ. The ferric reducing ability of plasma (FRAP) as a measure of "Antioxidant power" The FRAP assay. Anal Biochem, 1996; 239: 70-76.

5. Blois MS. Antioxidant determinations by the use of stable free radical. Nature, 1958 \& 2000; 81: 1199-2000.

6. Bradacs G., Ethanobotaniocal survey and Biological screening of medical plants from Vanutau Ph.D. dissertation. Germany: University of Regensburg. (2008); p. 171.

7. Bray HG and Thorpe WV. Analysis of phenolic compounds of interest in metabolism. Meth Biochem Anal. (1954); 1: 27-52.

8. Choudhary $\mathrm{K}$ and Singh $\mathrm{M}$, Ethnobotanical Survey of Rajasthan-An Update. Am Euras J Biotech. (2008); 1:38-45.

9. Defl ilipps AR and Maina LS. The Palauan and Yap Medical Plant Studies of Masayoshoi okabe. Atoll Res Bull. (1988); 17.

10. Erkan N, Ayranci G, Ayranci E. Antioxidant activity of rosemary (Rosmarinus officinalis) extract, Black seed (Nigella sativa) essential oil , carnosic acid, rosmarinic acid and sesamol. Food Chem, (2008); 110:76-82.

11. Fallah HSM, Alavian HR, Heydari MR, Abolmaali K. The efficacy of Liv-52 on liver cirrhotic patients: a randomized, double blind, placebo-controlled first approach. Phytomedicine. (2005); 12(9):619-624.

12. Garden CA and Bennet HW. The Toxic Plant of Western Australian ath. West Aust News Paper. (1956).

13. Ghoshal S, Tripathi VK, Chauhan S. Active constituents of Emblica officinalis. Part I, the Chemistry and antioxidative effects of two hydrolysable tannins, emblicanin A and B. Indian J Chem, (1996); 35 (B): 941-948.

14. Grubben GJ and Denton OA. Plant Resources of Tropical Africa. Vol. 2:Vegetables. Backhuys. (2004); p. 166.

15. Gulcin I. The antioxidant and radical scavenging activities of black pepper seeds. Int J Food Sci Nutr, (2005); 56: 491-499.

16. Gupta A, Kumar D, Kumar S, Gupta J and Arya R, A review on chemical and biological properties of Cayratia trifolia Linn. (Vitaceae). Phcog Rev; (2011); 5:184-8.

17. Gupta AK and Sharma M. Review on Indian Medical Plants. New Delhi, India: ICMR; (2007); 5:879-82.

18. Gupta J and Kumar D. A review on chemical and biological properties of Cayratia trifolia Linn. (Vitaceae). Pharmacognosy Reviews. (2011); 5(10):184-188.

19. Gupta J, Kumar D and Gupta A. Evaluation of gastric antiulcer activity of methanolic extract of Cayratia trifolia in experimental animals. Asian Pacific Journal of Tropical Disease. (2012); 99-102.

20. Gupta SS. Prospects and perspectives of natural plant products in medicine. Ind. J. Pharmacol. 1986; 26:1-12.

21. Jayaraman J. Laboratory Manual in Biochemistry, (Wiley Eastern Limited, New Delhi, (1980 \& 1981); pp. 96-97.

22. Kumar D, Gupta J, Kumar S, Arya R. Pharmacognostic evaluation of Cayratia trifolia (Linn.) leaf. Asian Pacific Journalof Tropical Biomedicines. (2012); 2:6-10.

23. Lee CC and Houghton P. Cytotoxicity of plants from Malaysia and Thailand used traditionally to treate Cancer. J Ethnopharmacol. 2005; 237-43.
24. Lewington A. Medicinal plants and plant Extracts: A review of their importation into Europe. Cambridge, UK: Traffic International. (1993);

25. Liu Y and Yang L. Early metabolism evaluation making traditional Chinese medicine effective and safe therapeutics. J. Zhejiang University 2006; 7:99-106.

26. Loomis WE and Shull CA. Methods in Plant Physiology, (McGraw Hill Book Co., New York,). (1973);

27. Manjuhatta BK, Krishna V, Pullaiah T. Flora of Davanagree district, Karnatka, India: Regency; (2004); p. 94.

28. Maurya R and Gupta CM. Traditional herbs for modern medicine. Tech Monitor, (2006); 43:23-36.

29. Maurya R, Gupta CM. Traditional herbs for modern medicine. Tech Monitor 2006; 43:23-36.

30. Mc Cready, R. M., Guggolz, J., Silviera, V., And Owens, H. S. Determination of starch and amylose in vegetables. Anal. Chem. (1950); 22:1156.

31. Munchen, Staatssamml. Protabase Record Display 1953;1:352.

32. Ncube NS, Afolayan AJ, Okoh AI. Assessment techniques of antimicrobial properties of natural compounds of plant origin: current methods and future trends. Afr. J. Biotech. (2008); 7 (12):1797-1806.

33. Osborne DJ. Effect of kinetin on protein and nucleic acid metabolism in Xanthium leaves during senescence. Plant Physiol. (1962); 37: 595-602.

34. Pulliah T. Encyclopedia of World Medical Plants. India: Regency; (2006); 1:492.

35. Purushothama S, Viswanath S, Kunhikannan C. Economic valuation of extractive conservation in a tropical deciduous forest in Madhya Pardesh, India. J Trop Eco., (2001); 41:61-72.

36. Rajeshwar Y, Gupta M, Mazumder UK. Antitumor and in vivo antioxidant status of Mucuna pruriens (Fabaceae) seeds against Ehrlich ascites carcinoma in Swiss albino mice. Iranian J Pharm Ther, (2005); 4: 46-53.

37. Rimbach G, Fuchs J, Packer L. Application of nutrigenomics tools to analyze the role of oxidants and antioxidants in gene expression. In: Rimbach G, Fuchs J, Packer L (eds.), Nutrigenomics, Taylor and Francis Boca Raton Publishers; FL, USA: (2005); pp. 1-12

38. Safarzadeh E, Sandoghchian S, Baradaran B. Herbal medicine as inducers of apoptosis in cancer treatment. Advanced Pharmaceutical Bulletin; (2014); 4(Suppl 1):421-427.

39. Saha MR, Hasan SMR, Akter R, Hossain MM, Alam MS, Alam MA. In vitro free radical scavenging activity of methanol extract of the leaves of Mimusops elengi Linn. Bangladesh J Vet Med, (2008); 6:197-202.

40. Sesagirriravu R, Flora of Srikakulam district, Andhra Pardesh. J Ind Bot Soc India; (1986); 147.

41. Soejima A and Wen J. Phylogenetic analysis of Grape Family (Vitaceae) based on three chloroplast markers. Am J Bot. (2005); 93:278.

42. Throton WBC. Krakatau. Harvard University Press. (1997); $121,155$.

43. Tutul E and Uddin MD. Z, Angiospermic fl ora of Ructia Sal Forest (Bangladesh). Bangladesh J Plant Taxon. (2010); 17:3345.

44. Vardana R., Direct use of medical plant and their identifi cation. New Delhi, India: SARUP and Sons; (2008); 1:177.

45. World Health Organization. Quality control guidelines for medicinal plant materials. Geneva: World Health Organization. (2008);

46. Yin SY, Wei WC, Jian FY, Yang NS. Therapeutic applications of herbal medicines for cancer patients. Evidencebased Complementary and Alternative Medicine. (2013); 20:302.

47. Youwei Z, Jinlian Z, Yonghong P. A comparative study on the free radical scavenging activities of some fresh flowers in southern China. LWT Food Sci Technol, (2008); 411:15861591. 